\title{
İran'da Feminizmin Gelişimi
}

\author{
Pouneh Abdollahifard*
}

\section{Öz}

Kadim medeniyetlerin beşiği olarak uygarlık tarihi içerisinde müstesna bir yere sahip olan İran, coğrafi konumunun da etkisiyle birçok kültürün buluşma noktası olmuştur. Bu noktada bir medeniyetin gelişim sürecini takip ederken kadınların o kültür içerisindeki konumunu tespit etmek önemli bir gösterge olarak karşımıza çıkmaktadır. Kadın olgusu, bu kadim medeniyetin eski dönemlerinden itibaren özel bir incelemeye tabi tutulacak bir tarihsel süreç yaşamıştır. Bu araştırma İran'daki kadın algısının tarihsel sürecini çözümleme açısından belli dönemleri ele almaktadır. Bu doğrultuda İran'da kadın hakları bağlamında meydana gelen gelişme ve buna karşıı olarak gerilemeler değerlendirilmektedir. Kaçarlar dönemi, Sanayi Devrimi sonrası dünyada başlayan kadın hareketlerine paralel olarak önemli bir yere sahip olmakla beraber sonrasında kurulan İran İslam Cumhuriyeti'nin kadına bakış açısı izlenmeye çalışılmıştır. Ele alınan dönemin olayları kadının hak mücadelesi bağlamında incelenirken, bunların İran siyasi, sosyal ve kültürel hayatındaki yeri de tespit edilmeye çalışılmaktadır.

Anahtar Kelimeler: İran, Feminizm, Kadın Hakları, Toplumsal Cinsiyet, Cinsiyet Eşitliği.

Dr. Öğr. Üyesi, Erzurum Teknik Üniversitesi, Edebiyat Fakültesi, Felsefe Bölümü, abdollahi.fard@erzurum.edu.tr, ORCID: 0000-0002-4928-2155. 


\title{
The Development of Feminism in Iran
}

\author{
Pouneh Abdollahifard*
}

\begin{abstract}
Iran has an exceptional place in the history of civilization as the cradle of ancient civilizations. As a matter of fact, Iran has become the meeting point of many cultures with the effect of its geographical location. At this point, while following the development process of a civilization, determining the position of women in that culture appears as an important indicator. The phenomenon of women has gone through a historical process that will be subject to special examination since the ancient times of this ancient civilization. This research handles a certain period in terms of analyzing the historical process of the perception of women in Iran. In this direction, the developments in Iran in the context of women's rights and the regressions against it are evaluated. Although the Qajars period has an important place in parallel with the women's movements that started in the world after the Industrial Revolution, the perspective of the Islamic Republic of Iran, which was established afterwards, was tried to be followed. While examining the events of the period under consideration in the context of women's struggle for rights, their place in Iran's political, social and cultural life is also tried to be determined.
\end{abstract}

Keywords: Iran, Feminism, Women’s Rights, Gender, Gender Equality.

Assist Prof. Dr, Erzurum Technical University, Faculty of Literature, Department of Philosophy, abdollahi.fard@erzurum.edu.tr, ORCID: 0000-0002-4928-2155. 


\section{Giriş}

Tarihi süreç boyunca siyasî, kültürel ve ekonomik koşullar insanların hayatları üzerinde cinsiyet gözetmeksizin etki bırakmıştır. İran tarihindeki sürekli tekrarlanan iniş çıkışlar ve köklü değişimler de siyasî ve sosyal yaşama bıraktığı etkilere bağlı olarak insanların hayatını ve toplumdaki konumlarını değişikliğe uğratmıştır. Bu değişim kadınların konumu açısından incelendiğinde ise çok daha hassas bir nokta ile karşılaşılmaktadır. Buna göre İran toplumu ekonomik ve siyasi açıdan güçlü olduğu dönemlerde kadınların toplumdaki değeri ve kıymeti artmıştır. Ancak ne zaman ki toplum genel anlamda düşüş veya yıkılış yaşamışsa kadınların konumu ve değeri de azalmaya başlamıştır. Hiçbir zaman değişmeyen tek şey ise kadınların aile içindeki değeri ve bu değerin toplumun siyaset yapma biçimi ve kültürü tarafından desteklenmesidir.

Tarihi kaynaklar incelendiğinde İran'da kültürün, siyasetin ve ekonominin keskin değişimlere uğradığı birkaç önemli geçiş süreci ile karşılaşılmaktadır. Bu geçiş aşamaları şunlardan ibarettir:

a) Aryalıların İran Platosuna yerleşmesi (Bu dönemde İran toplumunun ve siyasetinin temel alt yapısı oluştu)

b) İslam'ın Arapların aracılığı ile bölgeye yayılması (Bütün eski gelenekler etkilendi ve yeni gelenekler ortaya çıkmaya başladı)

c) Safevi Hanedanı'nın egemenliği (Şii düşüncesi ortaya çıktı)

d) Meşrutiyet Devrimi (Siyasetin bütün alt yapısı ve yönetim şekli tamamen değişti)

e) İran İslam Devrimi (İran'ın iç ve dış dünya ile ilişki şekli tamamen değişime uğradı)

Bu makalenin amacı kadınların hayatındaki ciddi değişimler için ilk hareketlerinden bahsederek bu sürecin gelişim seyrini anlatmaktır. Dünyadaki kadın hareketleri ile paralel olan hatta biraz geç kalmış sayılan İran'daki feminist hareketin ilk adımları, Kaçar Hanedanlığı döneminde atılmıştır. Sanayi Devrimi'nden sonra İran'da modernizmin ilk yansımaları ile birlikte basın-yayın ve modern üniversite eğitim sisteminin topluma yerleşmesi ${ }^{1}$

Bu konu hakkında daha detaylı bilgi için bkz. Pouneh Abdollahifard, "Nima Yuşic'ten 1979'a kadar Fars Şiiri”, (Doktora Tezi, Atatürk Üniversitesi, 2018). 
kadınların da zihin dünyasını derinden etkilemeye başlamıştır. İlk aşamada saraydaki kadınlar babaları, eşleri, erkek kardeşleri veya erkek evlatlarının vasıtasıyla dünya hakkında bilgi edinip haremdeki küçük dünyalarının sınırlarını genişletmeye çalışmışlardır. Bu küçük dünyadan açabildikleri bir pencere bulduklarında bazen okuma yazma veya eğitim şansı bularak kitaplara ve o dönem çıkan gazetelere ulaşabilmişlerdir. Hatta bazıları yabancı dil öğrenme şansına bile sahip olmuştur. Elbette bu arada en önemli etkenlerden biri de Kaçarlar zamanında padişahların ve siyasetçilerin bir kısmının Avrupa'ya seyahatleri olmuştur. Siyaseti yöneten bu insanlar bu seyahatlerde dünya kadınlarının mücadelesi, başarısı ve ellerindeki haklarını görmüşlerdir. Bu durum neticesinde de İran'da geleneklerin kadınların etrafında kaya gibi duran sert duvarlarında çatlaklar oluşmaya başlamıştır. Daha sonra yurt dışına eğitim için gönderilen öğrenciler de bu çatlaklarda ciddi kırılmalar yaratmayı başarmışlardır. Bu dönemde ilk olarak saraydaki kadınlar, hakları konusunda eskisi kadar yetinmemeye başlamışlardır. Eşleri ile yurt dışına giden bu saray kadınları ve eğitim/ticaret ve benzeri sebeplerle sürekli seyahatlerde bulunan aydın ve tüccarlar, kadınların İran'daki kapalı ortamına esin kaynağı olacak uyanış noktasında mühim rol oynamışlardır. Bu kadınlar daha sonra kendileri de yurt dışında eğitim alarak önce kendi dünyalarını ve daha sonra bütün ülkedeki kadınların dünyasını değiştirmeye çaba göstermişlerdir.

Kısa sürede bütün bu büyük değişimlere bir de Meşrutiyet Devrimi'ndeki kadınların ciddi rolü eklenince, Kaçarlar döneminin neden bu incelemedeki ilk dönem olması gerektiğinin yeri daha anlaşı1ır olmaktadır. Eklenmesi gerekir ki bu süreçleri sosyolojik açıdan daha dikkatli incelemek ve daha derinden araştırmak bir makale çerçevesinde imkânsız olduğu için konular özet olarak anlatılmıştır. ${ }^{2}$

Ele alınan dönem dışında İran'da kadının konumu hakkında detaylı bilgi elde etmek için bkz. Pouneh Abdollahifard, "Zerdüşt İnancında Kadının Konumu” Doğu Esintileri (2020): 263-286; Pouneh Abdollahifard, "Toplumsal Cinsiyet Bağlamında Siyasi Kimlik ve Temsil: Yerel Seçimler Örneğinde Kadın Politikacıların Seçim Afişlerindeki Mitler Üzerine Göstergebilimsel Bir İnceleme" (Doktora Tezi, Atatürk Üniversitesi, 2019); Pouneh Abdollahifard, "Kavramlar ve Kuramlar, Düşünce Bilimleri" içinde Iran Mitolojisinde Cinsiyet Essitliği, (ed) M. Nesim Doru- Kamuran Gökdağ (Mardin: MAÜ Yayınlar1, 2020), 575-591. 


\section{2. İran'da Kadın Hareketinin Başlangıcı Olarak Kaçarlar Dönemi}

\subsection{Kaçarlar Döneminin Kısa Bir Tarihi}

Kaçarlar dönemi, Zend hükümetinin yıkılmasından sonra Aga Muhammed Han tarafından XVIII. yüzyılın sonlarında başlamıştır. Bu dönemin en güçlü ve en uzun süre tahtta kalan padişahı olan Nâsıruddîn Şah (1848-1896) İran'ın bağımsız bir devlet olarak kalabilmesinin yapılacak köklü değişikliklere bağlı olduğunu idrak etse de başta Ruslar ve İngilizler olmak üzere dış devletler İran'ı her geçen gün daha da sıkıştırmışlardır. Üstelik babası Feth Ali Şah döneminde başlamış olan Avrupalılara imtiyazların verilmesi (petrol, tütün gibi ürünlerin alışveriş hakkı) Nâsırüddin Şah devrinde iyice hız kazanmıştır.

İmtiyazlar dolayısıyla XIX. yüzyılda Avrupa güçlerinin İran'a ekonomik olarak nüfuzu ve Batı kökenli fikirlerin İran'a girmesi, toplumun geleneksel yapısını derinden etkilemiştir. Bu süreçte faaliyetlerini gizli yürüten birtakım derneklerde yeni meselelerin tartışılması, sosyal ve hukukî reformların yanı sıra anayasanın ve meclisin teşkilini savunan hareketleri doğurdu. 7 Ekim 1906'da meclis toplanmasının ardından 30 Aralık'ta anayasa Muzafferüddin Şah tarafindan kabul edildi ve meşrutiyet ilan edildi. Ancak 1907 'de tahta çıkan Muhammed Ali Şah anayasayı ihlâl etmek ve meclisin faaliyetlerini askıya almak için elinden geleni yaptı. Bunun üzerine önceleri anayasayı hararetle desteklemiş olan ulema kesimi Batı kökenli reform taleplerinin giderek yoğunlaşması üzerine kendilerini geri çekmeye başladılar. İçte bu karışıklık yaşanırken dış güçler de İran aleyhindeki faaliyetlerini sürdürmekteydiler. ${ }^{3}$

Meşrutiyet hareketi, İranlıların hak ve hürriyet uğruna icra ettikleri tüm çabaların kararı olarak görülebilir. Bu hareket özgür düşünce ve yeni dünyaya açılan ilk kapı olma durumunu gösterirken, İran'ın yapısal değişiminde önemli bir role sahiptir. İran'da en temel siyasi ve sosyal değişiklikler Meşrutiyet döneminde başlamış ve bu dönem toplumun yeni dünya ile iletişime geçerek geleneklerden ve eski fikirlerden vazgeçilmesi yolunda ilk adım olmuştur. Meşrutiyetin etkisi sanat, kültür ve edebiyatta dolayısıyla da kadınların toplumdaki yaşamında kendini göstermiştir. Meşrutiyet dö-

İsmail Safa Üstün, “İran,” DİA, XXII, (İstanbul, 2002): 403. 
neminin başlangıç aşamasında İranlılar zorbalık ve düşünce körlüğü gölgesinde uzun bir tarih yazmışlar ve bu vaziyet Kaçarlar döneminde zirveye ulaşmıştır. Bu hanedanlığın hakimiyet yılları dünyanın tam yenilenme dönemine karşılık gelirken, Avrupalı devletler İran'ı kendi emellerinin yayılım alanı olarak görmüş ve tüm güçleri ile İran topraklarına saldırmaya çalışmışlardır. ${ }^{4}$ İran Meşrutiyet hareketi sadece idarî manada bir yenilenme dönemi değil, toplumsal hayatta da geniş çapta tesirleri olan bir dönemdir ve İran milliyetçiliğinin başlangıcı bakımından da ehemmiyet taşımaktadır. "Teceddud" ya da "Yenileşme", devrin aydınları tarafından devlet ile ulus arasındaki birlikteliğin tesisi ve tamiri olarak görülmüş, bu doğrultuda milli kimliğin devletle beraber tekrar şekillendirildiği yorumları yapılmıştır. ${ }^{5} \mathrm{Bu}$ arada Avrupa'da sanayileşme sonrası ortaya çıkan büyük güçlerin iktidar yarışı, imparatorlukların iç isyanlarla yüz yüze kalma süreci, başta Osmanlı coğrafyası olmak suretiyle bütünüyle Doğu'yu da etkiledi. İran'daki Meşrutiyet hareketi de Osmanlı ile aşağı yukarı örtüşen tarihlerde aynı olmasa da benzer motivasyonlarla gelişti. Buna paralel olarak Batılı şirketlerin Doğu coğrafyasında etkinleşmeleri yer altı kaynaklarının öneminin arttığı bir çağa denk gelmekteydi. ${ }^{6}$

\subsection{Demokratikleşme ve Modernleşme Sürecinde Kadın}

Nâsıruddîn Şah'ın yaklaşık elli yıllık egemenlik döneminde ortaya çıkan çeşitli etkenler özgürlük düşüncelerinin doğmasına neden oldu. Ayrıca yine bu dönemde modernleşmeyi önemseyen Nâibu's-saltana Abbâs Mirza, Kâim Makâm Mirza Ebu'l-Kasım gibi siyasetçilerin ilk teşebbüsleri sonucu fen bilimleri ve yeni sanatlar yaygınlaşmaya başladı. Mirza Takî Han Emir Kebir'in 1slahatlarıyla 1852 yılında Darülfünun'un ve basımevinin kurulması, baskı sanatının geliştirilmesi, yurt dışına öğrenciler gönderilmesi, gazete basılması, Avrupa'ya ait fikirlerle tanışılması ve bu türden konular değişim için atılan ilk adımlar oldu. Yurt içindeki ve yurt dışındaki aydınlar gazete ve kitap aracılığıly halkı aydınlatmak ve onlara yeni fikirler aşılamak için yazın hayatına başladılar. Bu çabaların hepsine rağmen

4 Abbas Bakinejad, Teemmuli der Edebiyat-i İmruz-i İan, (Tahran: Parsi, 1387 hş), 34.

5 Yalçın Sarıkaya, "Geçmişten Günümüze İran, Tarih, Siyaset, Toplum ve Kültür," Tasav, Rapor no. 2, (Ankara, 2012): 11.

6 Sarıkaya, “Geçmişten Günümüze Irran,” 12. 
maalesef Muzaffereddin Şah'dan sonra tahta geçen Muhammed Ali Şah, Haziran 1908 'de sıkıyönetim ilân ederek meclisi kapatmıştır. Anayasa taraftarları Tebriz'i işgal etmiş olan Ruslara rağmen Şah'ın bu hareketine karşı direnmeye çalışmışlar ve Temmuz 1909'da Şah'ı tahttan indirip yerine yedi yaşındaki oğlu Ahmet'i geçirmişlerdir. İki yıl sonra Muhammed Ali'nin yeniden tahtı ele geçirme teşebbüsü Rusların doğrudan müdahalesine yol açmış ve 24 Aralık 1911 tarihinde meclis tekrar kapatılmıştır. ${ }^{7}$

1904-1905 yıllarında gizli ve yarı gizli faaliyetlerle örgütlenen anayasa taraftarları İngiltere ve Rusya'nın artan baskı ve kontrolü ile eşzamanlı olarak 1905-1906 yıllarında sokağa çıkmışlardır. Encümenler etrafinda örgütlenmiş olan ve içlerinde gayrimüslim ve seküler misyonerleri ve kadınları da barındıran bu gruplar, din adamları sınıfı ile de iyi ilişkiler geliştirmiş̧lerdi. Zaman içinde meşrutiyetçilerin merkez bölgesi ülkenin kuzeybatısı yani Azerbaycan olmuştur. Tebriz merkezli gelişen bu meşrutiyet hareketi 1909 yılında İngiltere ve Rusya'nın ortak kararıyla bastırılmıştır. 19051911 senelerinin mücadeleleri İran halkının tarihinde önemli bir dönüm noktası olmuş, bu hareket halkın yönetime katılabildiği "anayasal hükümet" kavramını getirmiştir. Bu mücadeleler esnasında kadınların da varl1ğ1, değeri ve fikrinin önemi gün yüzüne çıkmaya başlamıştır. Bu olaylarda onların hem silahlı mücadeleye katılıp meşrutiyetçilerle birlikte savunma yapmaları, hem sundukları kıymetli fikirler, hem de cephe arkasındaki anaç destekleri bu başarının inkâr edilmez payı olarak görülmüştür. Netice itibariyle kadınların rolü, sadece anne ve eş olmaktan öte bir birey olarak ciddiye alınmaya başlamıştır. ${ }^{8}$

$\mathrm{Bu}$ olaylar yaşanmadan önce Kaçarlar döneminde eril iktidarın kadınlara dair algısı onların haremde veya evlerinin bir köşesinde yaşamaları gerektiği şeklindeydi. Onların evden çıkıp çarşıya pazara gitmeleri bile çok ciddi sıkıntı olarak algılanmakta, hatta bazı yerlerde günah sayılmaktaydı. O dönemde örtünme çok abartılı bir şekilde artmışt1. ${ }^{9}$ Kaçarların ilk yıllarında topluma hâkim olan yaşam şartları, eski dönemlerden tevarüs edilerek sonraki kuşaklara aktarılmaktaydı ve kadınlar toplumun bir parçası olarak yeterince eğitim alamamaktaydılar. Tabi ki kadınların bilgisizliği

Sarıkaya, "Geçmişten Günümüze İran," 13.

Sarıkaya, “Geçmişten Günümüze Iran,” 14.

Morteza Ravendi, Tarih-i İctimai-yi İran, c. 1, (Tahran: Nigah,1365 hş), 79. 
ve eğitimsizliği, onların toplumsal hayattan dışlanmasını gitgide daha da derinleştirmekteydi. ${ }^{10}$

Kaçar döneminde kadınların toplumsal katılımlarının en aktif boyutu $\mathrm{Mu}$ harrem ayındaki taziyelere katılmalarıydı. Eski kaynaklarda kadınların bu dönemde sürekli taziyeler (ritüel) ve taziye mahiyetli tiyatrolara katıldıkları bilgisiyle karşılaşılmaktadır. Gerçi bu katılımlarda bile kadınlar, toplumsal alanlarda sürekli tesettürlü bir şekilde alıştıkları ahlak kurallarını koruyarak ve deyim yerindeyse haremlik-selamlık biçiminde ayrı taraflarda gözükmekteydiler. O dönemde eğlence mekânları, dini mekânlar ve hatta türbe ziyaretleri bile kadınlar ve erkekler için ayrı ayrıydı. Bazı yerlerde ise kadınların toplumla doğrudan iletişim kurmaları yerine, eşlerinin ya da çocuklarının aracılığıyla dolaylı iletişim kurdukları dikkat çekmektedir. Buna rağmen kadınlar eşleri üzerinde etki bırakarak dolaylı bir şekilde girdikleri ortamları yönetmeye çalışmışlardır. ${ }^{11}$

Bu siyasî kargaşada kadınların varlıklarını ortaya koymak için başka bir yöntemleri ise vakıflara ve hayır derneklerine katılımları olmuştur. Bu durum, genelde saraydaki ve şehirli zengin kadınlara özgü olsa da o dönemde kadınlar için bir tür sosyal hayata katılım ortamı sağlamıştır. Tarım ve hayvancılıkla geçimin sağlandığı kırsalda geleneksel yaşantı süren kadınlar ise tarımsal ve hayvansal üretimde ailelerine yardım edip, aynı zamanda el sanatlarıyla ev ekonomisine destek olarak toplumsal hayatta var olmaya çalışmışlardır.

Meşrutiyet mücadelelerinden sonra bile uzun yıllar boyunca İran'ın siyasî çehresi tamamen eril bir çehredir ve özgürlük talebi, sınırlı ölçüde kadının hayatına, o da sırf yazı, şiir ve makale çapında girebilmiştir. Bu dönemin şehirli kadınlarının sosyal hayata katılımları oldukça kısıtlıdır. ${ }^{12}$ Kaçarlar döneminin ilk yıllarında kadınların zengin ya da fakir olmalarına genel olarak eğitimsiz bırakıldıkları ve kültürel donanım açısından çok geride kaldıkları söylenebilir. Hatta düşünce, cinsiyet ve kişilik yönünden sürekli sömürü altında oldukları, siyasî, hukukî ve toplumsal birçok haktan mah-

10 Delriş Beşeri, Zen der Dore-yi Kaçar, (Tahran: Sazman-i Tabligat-i İslami, 1375 hş), 63.

11 Mansureh İttihadiyye, “Zen der Came’e Kaçar,” Kelk Dergisi, no. 55, (1373 hş): 4762.

12 Kar Mihrengiz, Muşareket-i Siyasi-yi Zenaân, (Tahran: Roşengeranü, 1379hş), 7-8. 
rum edildikleri bilinmektedir. ${ }^{13}$ Sadece Meşrutiyet mücadelelerinin başar1sından sonra kadınlar yavaş yavaş kişisel özgürlüklerini ve özlük haklarını fark etmeye başlamışlardır. Bu gelişmede meşrutiyet mücadelelerinde yer alan kadınların kendi güçlerinin farkına varmaları ve saraylı-şehirli İranlıların ağırlıkla Avrupa'ya seyahatleri, diğer bir deyişle yurt dışına çıkışları, kadınların zihin dünyalarının değişiminde, özgürlük isteklerinin şekillenmesinde etkili olmuştur.

\section{3. İlk Kadın Hareketleri ve Onların Talepleri}

Kaçarlar dönemindeki ilk kadın hakları savunucuları meşrutiyet yıllarında dergiler çıkararak ve kadın derneklerini kurarak İran'daki kadın hareketlerinin temelini oluşturmaya başlamışlardır. Aşağıda detaylı olarak ele alınan bu ilk kadın hakları savunucuları İran'da kadınların aleyhine olan şartların değiştirilmesi için birkaç temel ihtiyaç belirlemişlerdir. Bunlar: kadınların eğitimi, özellikle aile ve medeni konularda kadınlarla ilgili kanunların değişimi, tesettür zorunluluğunun ortadan kalkması, oy hakkı mücadelesi ve kadınların siyasete dâhil olması idi. Meşrutiyet döneminden sonraki kadın hareketlerinin ana hatları: kadınların sağlık hizmetlerine ulaşabilmesi, onlara çalışma imkânı sunulması, çalışanların iş şartlarının kolaylaştırılması, kadınların ekonomik faaliyetlere katılabilmesinin sağlanması, onların toplumdaki ve ailedeki konumunun yüceltilmesi ve daha üst düzeye aktarılması gibi konulardan oluşmaktaydı.

\subsubsection{Kız Çocukları İçin Eğitim Hakkı}

Kız çocukları için okulların açılması ve kadınların eğitim hakkı kazanması meşrutiyet döneminde kadın aktivistlerin en büyük dileği idi. Meşrutiyet devriminden sonraki ilk yıllarda kadın aktivistler arasında eğitime ilişkin farklı bakış açıları bulunmaktaydı. Örneğin muhafazakâr kadınlar gurubu sadece eğitimli anneler yetiştirilmesi için eğitim meselesini önemsiyorlard. Kadınların uyanışının en temel koşulunu eğitim olarak gören feministler ise hem kız çocuklarının hem de yetişkin kadınların eğitim alabilmesi için okullar açılmasını ısrarla istemektelerdi. Kaçarlar döneminde kızlar

13 Natık Homa, "Negahi be Barhi Neveşteha ve Mobarezat-i Zenan der Dore-yi Meşrutiyet," Kitab-i Com'e, no. 30 (1358 hş): 47. 
için eğitim mekânları sadece yedi yaşına kadar okuma-yazma ve kıraat eğitiminin verildiği Kur'an mektepleriydi. Bu çocuklardan anne babaları eğitimli olanlar ise eğitimlerini evde özellikle de babalarının yanında görmekteydiler. ${ }^{14}$

Bazı Amerikalı ve Avrupalı dini eğitmenler tarafından kurulan okullar açılsa da bu okullar sadece gayrimüslim k1zlara özeldi. 1875'ten sonra Müslüman kızların da bu okullarda eğitim almasına izin verildi. Bahsi geçen okullardaki eğitim sadece üst düzey ailelerin ve zengin kesimlerin kızlarına mahsustu ve kadınların genel bir eğitim alabilmesi için hala uzun bir yol vardı. Bu yabancı okulların açılmasından 30 yıl sonra gerçekleşen Meşrutiyet harekâtı ile birlikte kız çocukları için ilkokullar önce Tahran'da ardından da diğer şehirlerde açılmaya başladı. Bu istek pek de olumlu karşılanmadı. İlk kadın hareketlerinin aktivistleri dini ve geleneksel muhaliflerin tehditleri ve baskılarıyla savaşarak bu okulları açtırmaya çalıştılar. ${ }^{15}$

1906 yılında Tahran'da yapılan bir protesto yürüyüşünde çok ciddi talepler ortaya konuldu. Bu taleplerden biri kız çocukları için okul açılması, diğeri ise çok ağır çeyizlerin sunulması yerine bu çeyizlerin parasının kızların eğitimi için harcanması idi. Kadınlar 1910'dan 1911'e kadar yaptıkları konferanslarda kızlar için eğitim hakkı isteklerini sürekli öne sürdüler ve meclise yazdıkları dilekçelerde de okul taleplerini ön plana koydular. Aynı zamanda gazetelerde makaleler kaleme alındı ve toplu yazılan itiraz mektupları da kadınların eğitimine muhalif olan Meşrutiyetçi din adamlarına gönderildi ve onları ikna edebilmek için ciddi çaba harcandı. Hebl-ül Metin gazetesinde İmza-i Mahfuz mahlasıyla bir kadın tarafından yayınlanan makalelerden birisi kadınların eğitimini dini kurallara aykırı gören Şeyh Fezlullah Nuri'ye cevap olarak yazılmıştı ve şöyle ifadeler içermekteydi:

Ĕger sizin kastınız kadınların hiç eğitim almaması gerektiği, kadınların hayvanlar gibi yetişstirilmesi gerektiği ve bunun da Allah'ın buyruğu olduğu ise söyleyin; Allah bunu Kuran'ın neresinde yazmıştır ve hadisin neresinde mevcuttur? Eğer bu gerçekten Allah'ın buyruğuysa Allah'ın kadınlara bu kadar ilgisizliği-

14 Nuşin Ahmedi-yi Horasani, "Ez Mehafil-i Zenane ta Teşekkolha-yi Müstekil-i Zenan, Rahi be Suye Came'e-yi Medeni," Ferheng ve Tose'e, no. Kadınlara Özel Sayı, (1376 hş): 83-112.

15 Muhammed Rahim Eyvezi, "Zenan-i İrani Der Meclis-i Şura-yi İslama”, Zen Der Tovse'e ve Siyaset, no. 10, (1393 hş): 112-126. 
nin, evliya ve peygamberlerin kadınları bu kadar aşă̆llamasının sebebi nedir? Ve ĕger dinde kadınlar bu kadar aşă̆llı ise niye yeryüzüne inen bu dini hükümlerin yerine getirilmesi onlara tavsiye edilmiştir? ${ }^{16}$

Görüldüğü gibi kadınların eğitim talepleri aynı zamanda siyasal sistem ve ülkenin ortak sorunları için çare olabilmesi adına da taleplerdi ve bu talepler seküler açıklamalarla desteklenmekteydi.

\subsubsection{Medeni Kanunlarındaki Kadın Haklarına İlk İtirazlar}

Aile kanunlarında örneğin kadınların eşlerinden kolay boşanabilmesi, çok eşlilik, mecburi evlilikler veya kızların çocuk yaşta evlendirilmesi gibi problemler de meşrutiyet döneminde kadın haklarını savunanlar tarafından gündeme getirilen hususlardandi. O dönemde Efsaneh Vezirî’nin ifadesiyle erkekler kum gibi eş alıp canları çektiğinde boşayabilirdi ve bunun için hiçbir kurala tabi değildiler. Kadınlar içinse hiç bir hak gözetilmemişti. Aile içinde kadınlara zorla dayatılan eşitsizlikler, üst kesim ve aydın kadınlar tarafından da çok eleştirilmekteydi. Bu savaş üst kesim kadınlarla orta düzey kadınların müşterek savaşıydı. ${ }^{17}$

Meşrutiyet döneminin kadın hareketlerinin tanınmış aktivistlerinin hayatlarına bakılınca ilk göze çarpan Nasireddin Şah'ın kızı Tacussaltana'nın yaşadıklarıdır. Tacussaltana çok küçük yaşta Şah tarafından zorla evlendirilmişti. O, evlendikten 22 yıl sonra anılarını yazmış, orada 8 yaşında evlendirildiğini ve o dönemi hatılladıkça hala ellerinin ve ayaklarının titrediğini belirtmiştir. Kadınlara yapılan haksızlıklara artan bu itirazlar, kadınların o dönemdeki ortak acılarının dile gelişiyle ve aile kurallarının değişmeye başlamasıyla toplumsal ve ekonomik tabakaların sınırlarını aşan bir isteğe ve mücadeleye dönüştü. Tabii ki bu itirazın sesi aydın ve zengin kadınlar tarafından daha çok duyulmaktaydı. Bunun sebebi de onların eğitimli olmaları ve gazetelere ulaşabilmeleriydi. Kadın aktivistler özellikle meşrutiyetin ikinci döneminde yani 1909'dan 1911'e kadar olan süreçte çok eşlilik ve boşanma gibi temel hak ihlallerine çok ciddi itirazlarda bu-

16 Ali Bağdar-i Dilgüşa, "Berrisi-i Mutalibat-i Zenan der Metbuat_i Devre-i yi Meşrutiyet”, (Yüksek lisans Tezi, Firdevsi Üniversitesi, 1394 hş), 70-95.

17 Ali Rıza Semii İsfehani, "Revş ve Nezeriye-yi Feministi", Pejuheşname-yi Ulum-i Siyasi, (1392 hş): 153-168. 
lundular. Aktivistler gazetelerde, kadınlara özel ve hatta bazı genel içerikli dergilerde aile ve kadın haklarının eşitsizliğine dair itiraz içeren makaleler yazmaya başladilar. ${ }^{18}$

Bu itirazlar sürecinde eşitsizliğin kökü İslâm veya genel olarak dinde görülmemekteydi. Erkekler ve din adamları bu eşitsizliği yaydıkları ve uyguladıkları için eleştiriliyorlardı. Efsaneh Necmî-yi Abedi'nin dediğine göre o dönemde İslâmi yapı kadın aleyhtarı değildir. Ama din adamları bu itirazları dinin aleyhine ve dine itiraz olarak algılayıp sürekli bu konuyu kullanarak kadınları bundan vazgeçirmeye çalışmaktaydılar. ${ }^{19}$ Böyle bir bakış açısına rağmen kadınlar da hemcinslerine çektirilen cefaların karşısına geleneksel yöntemleri kullanarak geçmeye çalıştılar. İsmet Müstevfî-yi Aştiyanî adlı kadının eleştirel makaleleri buna çok güçlü bir örnek sayılabilir. Bahaî bir kadın olan İsmet Müstevfî, Bilge Hanım'ın Layihası adlı makaleler serisini İran-1 Nev dergisinde 1909 y1lında yayımlamaya başlad. Bu makalelerde erkeklerin birden fazla kadınla evlenmelerini eleştirip, "acaba erkekler de kadınların çok eşliliğine tahammül eder mi?" diye bir soru sormuştur. En önem verdiği ve gündeme getirdiği konulardan birisi de boşanmanın kolay olması ve çok eşlilik sebebiyle kadınların evliliklerine güvenmemeleridir. ${ }^{20}$

O dönemde kız çocukları için ilkokullar kurucu kadınların kendi paralarıyla oluşturuldu ve şekillendirildi. Bazen öğrencilerden de ücret alınmaktaydı. Buna rağmen bütün bu okullarda burslu öğrenciler için özel kontenjanlar bulunmaktaydı ve bu öğrencilerin eğitim masrafları kadın hakları savunucuları tarafından karşılanıyordu. Bazı sanat programları, özellikle de kadın sanatçıların programları, kızların eğitim masraflarını karşılamak için sahneleniyordu. Örneğin 1910'un baharında Atabey parkındaki bir tiyatro gösterisinde kız okulu kurmak için ve bir adet kadın sağlık ocağının açılması için fazlasıyla para toplandı. Ayrıca 1910 yılından sonra kadın hareketleri ve kadın dernekleri tarafından kızlar için ücretsiz okullar tesis edildi ve burslu öğrencileri bu okullarda okutmak için çok ciddi faaliyetler yapıldı. Hatta bazen bu öğrenciler için ücretsiz kıyafet ve kırtasiye malze-

18 Tacussaltana, Hatirat, tsh, Mansure İttihadiye (Tahran: Neşr-i Tarih-i İran, 1371 hş), 58-61.

19 Kar, Muşareket-i Siyasi-yi Zenaân, 69.

20 Eliz Sansariyan, Conbeş-i Hukuk-i Zenan der Iran, çev. Nuşin Ahmedi-yi Horasani (Tahran: Ahteran, 1384 hş), 83. 
meleri bile dağıtıldı 1918 yılında ise kadın aktivistlerin çabalarının sonucu olarak kızlar için Tahran'da devlet tarafından kurulan 10 okul eğitime başladı. Kadınların eğitimlerinin genelleşmesi ve kızlar için okul tahsis edilmesi, aslında meşrutiyet döneminde kadın aktivistlerin en büyük başarısıdır. Hatta bu başarı kadın aktivistlerin o dönemdeki tek kazancıdır denilebilir. $^{21}$

\subsubsection{Kadınların Giyim Tarzında Değişimler}

Kadınların örtünme zorunluluğu konusu, yoğun olarak Rıza Şah döneminde gündeme gelmiş olsa da bu konudaki muhalif sesler ilk kez meşrutiyet döneminde ortaya çıkmıştır. O dönemde örtünme konusuna yapılan itirazlar, başın örtülmesi, saçın açıklığı konusunda değil kadınların tesettür kıyafetlerinin biraz azaltılması gerektiğine dairdi. Giyim tarzı çarşaf ve peçe olan o dönem kadınının toplumda özgür olması ve erkeklerle paylaştıkları ortamlarda eşit hareket etmesi pek mümkün görünmemekteydi. İlk kez 1848 yılında Babî hareketinin kadın liderlerinden olan Tahire Gürretülayin, peçesini herkesin önünde açması bu konuda öncü oldu. Meşrutiyetten sonra da bazı eğitimli kadınlar, özellikle yurt dışında eğitim almış olanlar, peçelerini çıkararak örtünme zorunluluğu hakkında muhalif makaleler yazdılar ve ortamı kıyafet değişimine hazırladılar. Bu dönemde İsmet Müstevfî gibi kadınlar daha radikal bir hareketle aile ve dostlarının ortamında başörtülerini tamamen çıkardılar. Ama bu hareket toplum geneline yayılmadı. Bu esnada Müslüman kadınlarla gayrimüslim kadınların siyasî ve toplumsal ortak faaliyetler yaptığı mekânlar, örtünme konusunda Müslüman kadınları çelişkiye düşüren ilk ortamlar oldu. $\mathrm{O}$ dönem gayrimüslim kadınlar da kamusal alanlarda Müslümanlar gibi kapanmaktaydılar, ama daha özel ortamlarda başörtüleri yoktu. Gayrimüslim kadınların Müslüman kadınlarla sürekli ilişki halinde olmaları toplumda bir ikilem oluşmasina sebep oluyordu. Böylece genelde meşrutiyet döneminde örtünme zorunluluğuna muhalefet eden kadınlar, Babî, Bahayî ve diğer gayrimüslim kadınlardan etkilenmekle suçlanıyorlardı. ${ }^{22}$

21 Sansariyan, Conbeş-i Hukuk-i Zenan der Iran, 86.

22 Ahmedi-yi Horasani, "Ez Mehafil-i Zenane ta Teşekkolha-yi Müstekil-i Zenan, Rahi be Suye Came'e-yi Medeni”, 87. 
Yukarıda görüldügü üzere meşrutiyetin ilk yıllarında kadın aktivistler sadece kız çocukları için okul açmak konusunda mücadele ediyorlardı ve kapanma meselesini pek gündeme getirmiyorlardı. Çünkü örtünme zorunluluğuna eleştiri getirmek, kızlar için eğitimi daha da zorlaştıracaktı. Zaten kapanmayı ortadan kaldırma meselesi kız okullarının aleyhine yapılan ilk suçlamalardan birisiydi. O dönemde bir kadının saçları kapalı bile olsa sadece peçesini kaldırması ve yüzünün görünmesi bile hayâsızlık olarak görülmekteydi. Bu çok kapalı kıyafet zorunluluğu dini bir vecibe olarak öne sürülmekte ve kız çocuklarının okula gitmesine engel teşkil eden bir durum olarak görülmekteydi. O dönemde toplumun hem geleneksel hem dindar kesimleri ciddi bir şekilde buna tepki vermekteydi. Bu yüzden meşrutiyetçilerin çoğu bu suçlamaya maruz kalmamak için bu hareketten uzak durmaya çalıştılar. Örneğin 1907 yılında bir grup kadın başörtüsüz bir şekilde Tahran'da sokağa çıkıp "yaşasın meşrutiyet, yaşasın özgürlük" sloganlarıyla yürüyüş yaptıklarında, meşrutiyetçilerin çoğu bu göstericilerle her türlü bağlarını inkâr ederek onların düşmanlar tarafından kullanılan ve meşrutiyetin ismini lekelemek için ortaya çıkmış hayâsız kadınlar olduklarını iddia ettiler. Bazıları da onları Tahran'da devlet tarafindan parayla tutulmuş kötü kadınlar olarak tanıtmaya çalıştılar. ${ }^{23}$

$\mathrm{Bu}$ olayların doğru olup olmadığını bir tarafa bırakırsak ünlü tarihçi Beyat'in da dediği gibi o dönem İran toplumu radikal bir değişime hiçbir şekilde hazır değildi ve bu olay sadece bir örtünmeye muhalefet değil ciddi bir isyan hareketiydi. Kadınlar ve Yolları isimli kitabında Beyat, Tahran'da bir mescidin avlusunda kadınların protesto için toplandıklarını fakat bir direniş göstermeden vazgeçtiklerini anlatmıştır. "Başörtülerimizi bizden alacaksınız, camiden başlarımız açık çıkacă̆ız" diyerek camiden çıkmayı reddeden protestocu kadınlar, bundan bir sonuç alamamışlar ve yine çarşaflarıyla camiden çıkmak zorunda kalmışlardır. ${ }^{24}$

Belli bir guruba bağl1 ve organize olmayan bu gösterilere ek olarak bazı kadın hakları savunucuları da kapanmanın muhaliflerinden sayılmaktayd1lar ve bunun için çaba sarf ediyorlardı. Bu cesaretlerini de sürgünle, tehditle ve aktivitelerinin durdurulmasıyla ödüyorlardı. Zen dergisinin mü-

23 Muhammed Hüseyin Hüsrevpenah, Hedefha ve mobareze-i Zen-i Irani ez İnkilab-i Meşrute ta Saltanat-i Pehlevi, (Tahran: Peyam-i İmruz, 1381 hş), 61.

24 Hüsrevpenah, Hedefha ve mobareze-i Zen-i Irani ez Inkilab-i Meşrute ta Saltanat-i Pehlevi, 62. 
dürü Fehri Afakparsa Cihanî bir makalesinde kapanma aleyhinde ifadeler kullandığı için evine bir saldırı yapıldı ve Meşhed'den Tahran'a sürgüne gönderildi. Zenan dergisinin müdürü Seddige Devletabadî benzer bir makalesi sebebiyle, Name-yi Banivan adlı derginin müdürü Şehnaz Azat ise tesettürü hurafe ve gelenek gördüğü için tehdit edildiler ve dergilerinin yayını durduruldu. ${ }^{25}$

Bütün bu baskılara rağmen İranlı feministlerin bazıları o dönem İran nüfusundan meşrutiyetçilere göre sayıca çok az oldukları halde kadınların kapanması aleyhindeki çabalarına devam ettiler. Cemiyet-i Nisvanî Vatanhâh isimli aktivist guruba yön veren biri olan Muhterem İskenderî adlı kadın da bu konu hakkında birçok konuşma yaptı ve mitingler düzenlemeye çalıştı. Encümanî Muhadderatî Vatan Derneği başkanı Durratul Mealî kapanma için çok çabalar gösterip bu olayı kınadı. 1923 yılında Şehnazı Azat, eşi Ebul Kasım-1 Azat'la birlikte kapanma yasaklarının ortadan kaldırılması için Mecme-i Keşv-i Hicap Derneğini kurdular ve bunun için çok çaba gösterdiler ama bu dernek de kapatıldı. Ebul Kasım-1 Azat ise sürgüne gönderildi ve hapis cezası aldı. Bu hareketlere İran'ın bazı aydın erkekleri de destek verdiler. İrac Mirza 1924'te Tahran'da kapanma ve özgürlük hakkında yazdığ şiirlerinden dolayı kadınlardan birçok hediye aldı. ${ }^{26}$

Bütün bu çabaların sonucu olarak 1921'in başından itibaren Tahran'ın kuzey bölgelerinin bazı mahallelerinde kadınlar burkasız sokağa çıktılar. 1925 'te bazı kadınlar çarşafsız olarak sadece uzun mantolarla dışarı çıkmaya başladılar. Bu serbestlikler toplumun geneline yayılmadı ve kadınlar için bir kıyafet serbestliğine dönüşmedi. Fakat en azından feminist kadınların meşrutiyet dönemindeki isteklerinden birisinin kadınların örtünmelerine muhalefet olduğunu açık şekilde belirledi. ${ }^{27}$

\subsubsection{Kadınların Oy Hakkı Meselesi ve Siyasete Dâhil Olma Mücadelesi}

Kadınların oy kullanma hakları için mücadeleleri ise meclisin ilk döneminde 1907 senesinde meşrutiyetçi erkeklerin anayasayı belirlerken kadınları

\footnotetext{
25 Nasrin Musaffa, Muşariket-i Siyasi-yi Zenan der Iran, (Tahran: İntişarat-i Vezaret-i Umur-i Harece, 1375 hş), 34.

26 Maryam Pervin, “İnkilab-i Meşrute ve Conbeş-i Zenan”, Yad-i Eyyam, no. 59, (1389 hş): 75-89.

27 Ahmedi-yi Horasani, "Ez Mehafil-i Zenane ta Teşekkolha-yi Müstekil-i Zenan, Rahi be Suye Came'e-yi Medeni”, 89.
} 
oy hakkından mahrum ettikleri günden itibaren başlamıştır. Bu itirazlar meclisin ilk döneminde sadece makalelerle ve yazılarla ortaya koyulurken, ikinci döneminde yani 1911 'de meclisin gündemine de girdi. Hamedan milletvekili Muhammed Tekili Raya, mecliste açık bir şekilde kadınlara oy hakkı verilmesini istedi. Onun bu isteği diğer vekiller tarafından çok ciddi tepkiyle karşılandı. Fakat bu olay kadınların seçme hakkı meselesini gündeme taşıyan önemli bir başlangıç oldu. Bu konuyu yazılı olarak gündeme getiren ilk kişilerden olan Seddige Devletabadî, makalelerinde ve düzenlediği mitinglerde kadınların oy kullanma haklarının olması gerektiğini şiddetle savunmuş ve var olan uygulamaya şiddetle karşı çıkmıştır. Meclisin üçüncü dönem seçimlerinde Şukufe dergisinin kadın yazarları, seçme ve seçilme haklarından mahrum olmalarına rağmen 12 aday belirleyip dergide tanıtmaya başladılar ve erkeklerden bu adaylara oy vermelerini istediler. $\mathrm{Bu}$ gelişmeler sonucunda derginin yayını durduruldu. Fakat bu olay yine de kadınların siyasî hak taleplerinin önünü kesemedi ve mücadeleleri aynı şekilde devam etti. ${ }^{28}$

O dönemde kadınların seçme ve seçilme hakkını talep etmek sadece İran'da değil dünyanın hemen her yerinde oldukça radikal ve sert bir istek olarak karşılanmaktaydı. 1918'de İngiltere'de ve 1920'de Amerika'da aynı İran'da olduğu gibi feminist kadınlar hakları için mücadele etmekteydi. Kadınların eğitim hakkı istemelerinin bile garip karşılandı̆̆ı, görmezden gelindiği bir ortamda, seçme ve seçilme hakları bir öncelik sayılamıyordu. $\mathrm{Bu}$ çabalar, o dönemde sonuç vermemiş fakat daha sonraları kadın hakları savunucuları için bir yol haritası olmuş ve oy hakkı ve siyasete dâhil olma mücadelesi için bir temel teşkil etmiştir. ${ }^{29}$

\subsection{Dinî ve Politik Eksenli İki Önemli Olayda Kadınların Rolü}

Kaçarlar döneminde bir aktör olarak kadınların doğrudan katıldığı, onların toplumsal ve siyasal alandaki kaderini belirlediği ve etkilediği düşünülen dini ve politik eksenli iki önemli olay öne çıkmaktadır. Bu olaylar; Babîye ve Tütün Hareketi olarak bilinmektedir. On dokuzuncu yüzyılın ilk yarısında içtimaî sorunlar ve ekonomik zorluklar sebebiyle birtakım özgürlükçü

\footnotetext{
28 Kar, Muşareket-i Siyasi-yi Zenaân, 84.

29 Kar, Muşareket-i Siyasi-yi Zenaân, 85.
} 
toplumsal hareketler/akımlar ortaya çıktı. Bunlardan özellikle kadın hakları ve kadının sosyal durumunun gelişmesi ve iyileşmesi bağlamında etki bırakan en önemli akım, Şeyhîye veya Babîye ismiyle bilinen harekettir. Şeyhîye tarikat1, Şeyh Ahmet önderliğinde Kerbela'da şekillenen, Yunan felsefesi ve Şiîliğin karışımı olan bir tarikattı. Bu tarikat Kaçar iktidarına isyan edip kadınların haklarını savunarak halkın toplumsal durumunun iyileşmesi için mücadele etti. Bu yüzden halkın birçok kesiminden özellikle de kadınlardan kendine taraftar toplamaya başladı. Bu akımın temel talepleri; ekonomik ve toplumsal durumun iyileşmesi, kadınların kapanma şeklinin değişmesi ve cinsiyet eşitsizliğinin ortadan kaldırılmasıydı. $\mathrm{Bu}$ hareketin önde gelen liderlerinin öldürülmesine rağmen, çoğunlukla sosyo-ekonomik ve sosyo-kültürel açıdan en düşük seviyede toplumsal haklara sahip olan kadınlar bu akımın içerisinde yer almaktan yine de vazgeçmediler ve Kaçar iktidarının aleyhine savaşıp bu amaç uğruna onlar da öldüler. ${ }^{30}$

İkinci hareket ise tütün satış haklarının bir İngiliz şirketine verilmesi ve tütünün haram ilan edilmesiyle başlamış ve "Tütün Hareketi" veya "Reji Hareketi” olarak tarihe geçmiştir. İran'daki saray kadınlarının tarihin farklı dönemlerinde perde arkasında siyasî olarak etkili oldukları bilinmektedir. $\mathrm{Bu}$ harekette de onların ciddi payları olduğu söylenebilir. İran'daki tütünün ve tütün ürünlerinin bütün alım satım haklarının Talbot adlı bir İngiliz şirketine verilmesi, 1888 'de halk tarafından çok tepki gördü ve daha sonra Hacı Mirza-yi Şirazî'nin fetvasıyla tütünün haram ilan edilmesi bunu bir isyana dönüştürdü. Nasreddin Şah'ın sarayındaki kadınlar haremde tütünü yasakladılar ve bütün nargileleri kırıp halka katılarak bu isyanı daha da körüklediler. Saray kadınlarının bu davranışı sayesinde Tahran'da orta tabakaya ait kadınlar da direnişe ve isyana katıldılar. Bu olay kimi tarihçiler tarafindan İran'ın toplumsal ve siyasal dönüşümü bağlamında ilk adım olarak görülmektedir. İsyanın başarıyla sonuçlanması İran'daki meşrutiyet devriminin alt yapısını oluşturdu. Kadınların bu olaydaki rolleri, Kaçar hanedanlığı dönemindeki kadının pek de bilinçsiz olmadığının göstergesi olarak okunabilir. Aynı zamanda bu olay o dönem erkekler kadar tütünü yoğun olarak kullanan kadınların tarihsel süreçte toplumsal katılımının ve siyasetteki etkinliğinin ilk işareti olarak kabul edilebilir. ${ }^{31}$

30 Natık, "Negahi be Barhi Neveşteha ve Mobarezat-i Zenan der Dore-yi Meşrutiyet", 53.

31 Hasan Kerbelayi, Karardad-i Reji ya Tarih-i Inhisar-i Duhhaniyat, (Tahran: Mobarizan,1361 hş), 32. 


\section{3. İran'da Kadın Hareketinin İlerleme Gerileme Süreci Olarak Pehlevîler Dönemi}

Meşrutiyet hareketinden sonra İran'da yaşanan siyasî dönüşüm kadınların durumunu da kapsamaktaydı. Şöyle ki bu süreçte farklı siyasî partiler kadınların eğitimi meselesini ve toplum içindeki durumlarının iyileştirilmesini programlarına dâhil ettiler. Bu mücadelede geleneksel düşünceye sahip kişiler, gruplar ve kurumların direnişi de onları yıldıramadı ve hatta mücadele şiddetini bile arttırdı. İran'ın içindeki ve dışındaki yabancı dilde yayımlanan gazeteler ve dergiler bile makaleler yayımlayarak kadın haklarını savundular, zor şartları ve eşitsizlikleri eleştirdiler. Rıza Şah'ın göreve gelmesiyle (1925-1941) birlikte geleneksel kültürü terk edip Batı kültürünü almak isteyen ve bu yöntemi ülkenin ilerlemesi için tek şart gören insanlar, en hassas görevleri ve en kilit makamları ele geçirdiler. Böylece idarî, toplumsal, ekonomik ve kültürel yenilenme politikası, ülkenin üst düzey yöneticilerinin ilk hedefine dönüştü. Bu kapsamda eğitim-öğretim ve ordu yapısında da geleneksel alt yapı terk edildi ve daha yeni hedefler oluşturuldu. ${ }^{32}$ Dönemin başlangıcındaki modernleşme siyasetiyle birlikte ülkenin bütün şehirlerinde ilkokullar ve liselerin sayısı artmaya başladı. Üniversite eğitimi ve yüksek eğitim imkânı da aynı şekilde çoğaltıldı. Hatta 1930 yılında kızlar eğitim almak için Avrupa'ya bile gönderildiler. Ülkenin içinde de peş peşe üniversiteler ve yükseköğretim kurumları açıldı ve kızlar farklı bölümlerde eğitim almaya başladılar. ${ }^{33}$

Kimi tarihçilere göre Rıza Şah saltanatının ilk on senesi, kadınların hayatlarında pek bir değişim yaratmadı. Dolayısıyla kadınların aslında bu ilk on y1llık dönemindeki durumu Kaçarlar dönemindeki durumlarından pek de farklı değildi ve Rıza Şah bunu değiştirmek için hiçbir çaba göstermedi. Ancak 1930'a kadar yönetim mekanizmasını şekillendirip iktidarını güçlendirdikten sonra keskin değişiklikler ortaya koydu. Bu dönemde İran'ın hukuk sistemi yeniden şekillendi. Özellikle medeni hukuk kuralları hem İslam fikhı ve hem de modern dünyadaki hukukî hükümlerden faydalanılarak yeniden oluşturuldu. Rıza Şah, İran toplumunun henüz hazır olmadığı, diğer bir ifadeyle yabancısı olduğu, yeni durumlara onları zorlamış, kadın-

\footnotetext{
32 Siyaveş Kesrayi, Çalişs-i Sonnet ve Modernite der İran, (Tahran: Neşr-i Merkez, 1384 hş), 84 .

33 Kar, Muşareket-i Siyasi-yi Zenaân, 102.
} 
ları hızlı bir şekilde modernleştirmek adına radikal kararlar almıştı. Bunun en açık örneklerinden biri, örtünmenin tamamen ortadan kaldırılması, baş örtmenin yasaklanmasıydı. Hatta toplumdaki yansıması bakımından Rıza Şah döneminin en önemli olayının bu olduğu söylenebilir.

Meşrutiyet tarihinin ikinci dönemi, basında yer alan kadınlar için daha da aktif bir dönem sayılmaktaydı. Onlar basın yoluyla isteklerini daha net haykırabildiler. Kadın hakları, kadın-erkek eşitliği, kadınların istekleri ve kadınların özgürlügü gibi kavramlar, meşrutiyetten önce sadece yurt dışında basılan dergilerde yer alabiliyorken, bu dönemde İran'daki kadın dergilerinde hem fikir yazılarında hem de edebiyatta kullanılmaya başlandı. Öte yandan bu mücadelelerin İran'ın birçok yerine yayıldığ 1 ve kadınların fili olarak çatışmalara bile katıldıkları da bir vakıadır. Hatta o dönemde yayınlanan bir dergi, Reşt ve Tebriz şehirlerinde parlamentonun yeniden kurulması için yapılan silahlı çatışmalara, kadınların erkek kılığına girerek silahlarıyla katıldıklarını yazdı. Buna göre sadece Tebriz'de 22 kadın, erkek kılığında savaşarak şehit olmuş ve onların kadın oldukları ancak cenazelerinde anlaşılmıştı. ${ }^{34}$

İsfahan kadınları da kadın (zen) sözcüğünün isimlerinde geçtiği ilk dergilerini yayımladılar. "Zeban-i Zenan" (Kadınların Dili) adlı bu dergi, kadının gözünden ve kadın kalemiyle yazılan ilk dergiydi ve on beş günde bir yayımlanıyordu. Üç yıl yayınına ara verilen dergi, Seddige Devletabadî’nin azmiyle tekrar yayımlanmaya başlandı. Encümen-i Azadi-yi Zenan'ın (Kadınların Özgürlük Örgütü) üyesi olan Devletabadî, İsfahan'da aldığı tehditler ve ona çektirilen eziyetler yüzünden ailesiyle birlikte Tahran'a göç etmek zorunda kaldı. Bu sefer dergiyi Tahran' da aylık olarak yayımlamaya devam etti ve dergiyi ayakta tutmak için oldukça çabaladı. Meşrutiyet döneminin tarihini kaleme alan yazarlara göre bu dergi sivri diliyle çok ses getirmiştir. Yazılarında İngilizlerin İran'daki nüfuzunu sürekli eleştirmiştir. Zeban-i Zenan dergisinden sonra adında kadın sözcüğü geçen veya doğrudan kadın konusunu ele alan pek çok başka dergi yayımlanmaya başladı. Örneğin Name-yi Banivan (Kadınların Mektubu), Alem-i Nisvan (Kadınların Dünyası), Zenan-i İran (İran Kadınları), Cihan-i Zenan (Kadınların Cihanı), Cümle-yi Zeban-i Zenan (Bütün Kadınların Dili),

34 Hüsrevpenah, Hedefha ve Mobareze-i Zen-i Irani ez İnkilab-i Meşrute ta Saltanat-i Pehlevi, 33. 
Cemiyyet-i Nisvan-1 Vatanhah-i İran (İran'ın Vatan Sever Kadınlarının Cemiyeti), Nesvan-i Şark (Doğunun Kadınları), Rahnima-yi Banivan (Kadınlar İçin Yaşam Kılavuzu), Peyk-i Saadet-i Nisvan (Kadınların Saadetinin Habercisi), Duhteran-i İran (İran'ın Kızları), Name-yi Banivan-i İran (İran Kadınlarının Mektubu), Rahnima-yi Zindigi ve Restahiz İran (İran'ın Değişimi ve Dönüşümü İçin Bir Kılavuz ) gibi dergiler yayımland $1{ }^{35}$

$\mathrm{Bu}$ dergilerin yanı sıra toplumsal ve siyasî faaliyetler yürüten kimi kadın örgütleri/dernekleri/cemiyetleri de bu süreçte aktiftiler. Bu örgütlere örnek olarak; Encümen-i Muhatterat-i Vatan (Vatan Kadınlarının Örgütü), Ercümen-i Azadî (Özgürlük Örgütü), Cemiyyet-i Nisvan-i Vatan (Vatan Kadınları Cemiyeti), Cemiyet-i Mecme-i İnkılab-1 Zenan (Kadınların Devrim Örgütü), Cemiyet-i Peyk-i Saadet-i Nisvan (Kadın Saadeti Örgütü) gösterilebilir. Bu oluşumların asıl amacı, kadınları ülkenin siyasî durumu hakkında bilinçlendirmek, özellikle de kadınların eğitimi için çabalamak ve kadınların haklarını kazanmaya çalışmaktı. Söz konusu örgütler, meclise sürekli baskı yaparak kadınlar lehine çıkarılan kanunlar yoluyla bu amaçları elde etmeye çalışmışlard $1{ }^{36}$

Tüm bu kadın odaklı yayın ve mücadelelerin sonucunda önemli bir kazanım olarak 1962'de kadınlar seçme ve seçilme hakkını elde ederlerken, ilk seçimlerde az sayıda kadın milletvekili seçildi. Bunların birkaçı ise bakanl1k gibi daha üst makamlara kadar yükseldi ama yine de toplumda önemli mesleklerin geneli üst düzey ailelere aitti. Böylece orta kesim insanların hayatında çok büyük bir değişim oluşmamıştı. Bu esnada modern kadın örneğiyle geleneksel kadın örneği arasında orta bir grup şekillendi. Bu orta grup kadınlar modern eğitim almakla birlikte geleneksel değerlerle de barışıktılar. Bu yeni nesil Batılılaşmayı tamamen reddetmekte ve bu tarz bir değişimi emperyalist bir hareket olarak görmekteydi. ${ }^{37}$

Kadınların 1968'den sonra parlamentoya girmesiyle birlikte, ilk milletvekili kadınlar toplumdaki kadınlarla gereken iletişimi kuramayıp, onların haklarını koruyamadıklarından dolayı kadın cemiyetinin arasında kendile-

35 Hüsrevpenah, Hedefha ve mobareze-i Zen-i Irani ez Inkilab-i Meșrute ta Saltanat-i Pehlevi, 57.

36 Bedrolmoluk Bamdad, Ez İnkilab-i Meşrutiyet ta İnkilab-i Sefid, (Tahran: İbn-i Sina, 1347 hş), 280.

37 Bamdad, Ez İnkilab-i Meşrutiyet ta İnkilab-i Sefid, 281. 
rine bir konum kazanamadılar. Bu meselenin temel sebepleri ise; onların -halk tarafından değil- sadece üst tabakanın oylarıyla meclise girmeleri, erkeklerin siyasî dünyasındaki tecrübesizlikleri, erkeklerin ortamlarını pek tanımamaları ve demokrasi konusunda yeterli bilgiye sahip olmamaları gibi konular idi. Hatta bu kadınların sembolik olarak mecliste bulunduklarına dair söylentiler bulunmaktaydı. İlerleyen süreçte halk arasında kadınların sırf mecliste olmalarının yeterli olmadığı düşüncesi yavaş yavaş yaygınlaşırken, medeni haklarıyla ilgili her konuda ve siyaset dünyası hakkında yeterli bilgiye sahip olmaları, halkla iletişime geçip sosyal ortamlarda bulunarak hakları için mücadele etmeleri gerektiği kanaati hâsıl oldu. ${ }^{38}$

Rıza Şah'ın saltanatı, İngiliz ve Rusların iktidara el koymasıyla sona erdi ve ardından oğlu Muhammed Rıza Pehlevî tahta geçti. Muhammed Rıza'nın hükümdarlığının ilk yılları da sadece kendi tahtını sağlamlaştırmakla geçti. Bu süreçte Pehlevî hükümeti İran'ın toplumsal ve siyasî alt yapısında kendi sistemini oturtmaya çalıştı. Muhammed Rıza'nın dönemindeki en önemli siyasî değişim petrol sanayisinin halka devredilmesiydi. Bu olayda etkileri pek görülmeyen kadınların, o dönem sadece çalışma ortamında kendilerine yer bulmaya ve yeni yeni sosyal hayatta temel insani haklara sahip olarak var olmaya çalıştıkları, dolayısıyla siyasî ve kültürel faaliyetlere pek iştirak etmedikleri dikkat çekmektedir. İş dünyası dışında da edebi ve kültürel aktivitelere katılarak politik dünyayı ancak uzaktan izlemişlerdir. O dönemin önde gelen kadın aktivistlerinden birisi Şâhit dergisinin yazarlarından olan Simîn Danışver idi. Bu dergi daha sonraları "Ulus" partisinin iletişim aracına dönüştü. Zaman içinde bu partiden ayrılan bir kol "Sazman-i Zenan-i Pişrov" (Öncü Kadınlar Örgütü) adı altında kısa zamanda örgütlenerek yayımladıkları dergilerin sayısını arttırdı ve o dönemin başbakanı Musaddık'ın iktidarına destek vererek zor günlerde onun arkasinda durdu. ${ }^{39}$

Pehlevi döneminde yapılan Keşf-i Hicap (Başörtüsü Yasağı) reform hareketi İran'daki kadınların etrafında çizilen en büyük duvarı yıkıp kadınları topluma taşıdı. Bu değişim kadınlar açısından olumlu gelişmeler barındırsa da birçok olumsuz yönü de bulunmaktaydı. İran kadını Pehlevî dönemin-

38 Muhammed Muhit Tabatabayi, Tarih -i Tahlili-yi Matbuat-i Iran, (Tahran: Be'sat, 1369 hş), 172-174.

39 Bamdad, Ez İnkilab-i Meşrutiyet ta İnkilab-i Sefid, 301. 
de çelişkilerin ve çatışmaların arasında kalmıştı. Bir taraftan geleneksel kültürden gelen baskı ve diğer taraftan yeni ve modern toplumun dayattığ baskı, sürekli çelişki içinde yaşamasına sebep oluyordu. Kadınlar, devletin asıl hedefinin Batılılaşma olduğu bir dönemde -biraz da devlet politikas1nın zorunlu tavrı dolayısıyla- topluma atılmış oldular ve bu duruma bilinçli bir şekilde hazır bulunmadıklarından ötürü ciddi toplumsal bir yük ve sorumlulukla karşılaştılar. Dönemin kadınları bu değişime uyum sağlamayı bazen başarırken bazen de pek üstesinden gelemediler ama her şeye rağmen sürekli siyasî toplantılara, gruplara, derneklere ve örgütlere katılmaya çalışarak kendilerini eğitmek için mücadele verdiler. Bu dönemdeki bütün çelişkilere, muhalefete ve siyasî buhranlara rağmen, kadınlar arasında başarılı, eğitimli ve güçlü bir grup yetişti. Bu kadınlar kendi konumlarını ve toplumdaki diğer kadınların kaderini değiştirmek için çaba gösterdiler. Ancak bu potansiyel güce ve bütün mücadele azmine rağmen topluma atıldıkları halde kadınların siyasî ortamlarda özgürce faaliyet yapamadıkları ve siyasî açıdan önemli konumlarda pek varlık gösteremedikleri dikkat çekmektedir. ${ }^{40}$

\section{4. İran'da Kadın Hareketinin İnişli-Çıkışlı Dönemi: 1979 Devrimi Sonrası}

İslam devriminden sonra kadınların İran'daki durumu birkaç açıdan değerlendirilebilir. Devrim sürecinde oluşan birlik ve ittifakın İran toplumunun en büyük kazancı olduğu söylenebilir. Bu süreçte bütün ayrılıklar ve farkl1lıklar ortadan kaldırılıp toplumun bütün kesimleri arasında -1rk, dil, din ve cinsiyet ayrımcılığı olmaksızın- güç birlikteliği oluşmuştur. Gerek protesto ve siyasî mitinglerde, gerekse devlet yapısındaki dönüşüm sürecinde yediden yetmişe herkes elbirliği ile çaba gösterdi. Bu birlik ruhu devrimin başarısındaki belki de en büyük faktördü. Devrimin alt yapısı şekillendikten sonra yavaş yavaş bu güç birlikteliğinde kopuşlar oldu ve tekrar düşünce ve fikir ayrılıkları ortaya çıkmaya başladı. Bu ayrılıklardan biri de cinsiyet ayrımcılı̆̆ıdı.

Devrimden bir süre sonra kadınlar tekrar geri plana itilirken, kadınların ailedeki kadim görevleri ön plana çıkarılmaya başlandı. İran-Irak Savaşı'nın

40 Kar, Muşareket-i Siyasi-yi Zenaân, 22-25. 
başlamasıyla kadınların toplumda çok önemli roller üstlendikleri gerçeği tekrar gün yüzüne çıktı. Savaş esnasında kadınların hem savaş meydanlarındaki hizmetleri ve hem cephe arkasındaki eş, anne, doktor, hemşire mühendis olarak görevleri önemli hale geldi. Kadınlar olmaksızın bu sürecin atlatılmasının imkânsız olduğu çok net bir şekilde ortadaydı. Bu dönemden sonra artık kadınların insanî gücü, cinsi güçlerinden daha çok göze çarpmaya başladı ve bu mesele onların toplumda kendilerine konum edinmeleri için ilk kapı oldu.

$\mathrm{Bu}$ dönemde eğitim, ekonomi, siyaset ve sağlik alanlarında önemli gelişmeler yaşandı ve yasalar çıkarıldı. Örneğin, okur-yazarlık seviyesinden başlayarak yüksek eğitim alanına kadar kadınların eğitim durumlarında nicelik ve nitelik açısından olumlu değişimler meydana geldi. Özellikle yükseköğrenim düzeyindeki gelişmeler çarpıcıdır. Üniversite sandalyelerinin yüzde ellisini kızların doldurduğu, öğretim üyelerinin çoğunluğunun kadınlardan oluştuğu, hatta kadınların yüksek eğitim alanında üst düzey idari görevleri bile elde edebildikleri görülmektedir. Bunların yanı sıra küçük şehirlerde ve kırsalda kızların hemen hemen hepsinin en az liseye kadar eğitim görmesi ve ailenin kültürel anlayışında bu konunun oturtulması, devrimden sonra kadınların elde edebildiği en büyük kazançlardandır.

$\mathrm{Bu}$ dönemde yapılan düzenlemeler kadınların eğitim alanında başarılı olmaları, ekonomi ve iş dünyasına atılmaları ve meslek hayatında daha iyi konumlar elde etmeleri için büyük bir destek olmuş, hatta onları idari görevlerin en üst düzeyine kadar taşımıştır. Bu yükseliş serüveninde "cam tavan" kavramıyla ifade edilen terfi ayrımcılı̆̆ 1 gibi büyük engeller olsa bile ekonomi dünyasında da devrimden sonraki İran toplumunda kadınlar, başarılı iş kadınları veya güçlü tüccarlar olmayı başarabilmişlerdir. Devrimden sonra sağlık alanında da kadınların hayatında temel değişimler olmuş, sağlik düzeyinde imkânlar çerçevesinde iyileşme ve gelişme sağlanmış, ayrıca sağlık sektöründe kadınların varlığı net bir şekilde artmıştır. Bu sektör kadınların en çok başarılı oldukları alanların başında sayılabilir.

Son olarak İran'da kadınlar açısından en hassas rol sayılabilecek nokta onların siyasetteki konumlarıdır. Devrim sonrası bu alanda kadınlar çok aktif bir şekilde görülmelerine rağmen, İran hala dünya standartlarına göre çok ilerde sayılmamaktadır. Üst düzey siyaset basamaklarına bakıldığında bu durumun daha da üzücü hal aldığı gözükmektedir. Kadın bakanların sayısı yok denecek kadar az olmakla birlikte şu anki hükümette cumhurbaşkanının sadece 3 kadın danışmanı bulunmaktadır. 
Günümüz İran siyasetinde kadınların biraz daha aktif olabildikleri alanlar millet meclisi ve daha kolay ulaş1labilecek olan yerel meclislerdir. $\mathrm{Bu}$ yüzden genel ve yerel seçimlere kadınların katılımı renkli ve görkemli bir atmosfer oluşturmaktadır. Yerel seçimlere katılım şartlarının daha kolay olması ve kadınların yaşadıkları şehirlerde aile, akraba, iş veya her türlü tanınmışlık imkânlarını kullanabilmeleri nedeniyle bu seçimlerde genel seçimlere göre çok daha fazla kadın aday ile karşılaşılmaktadır.

\section{1. İran İslam Cumhuriyeti Anayasasında ve Yasalarında Kadın Hakları ve Sorumlulukları}

Anayasanın üçüncü ilkesi, İran İslam Cumhuriyeti vatandaşı olan tüm bireylerin bütün haklara sahip olmasını gerektirir. ${ }^{41} \mathrm{Bu}$ maddenin amacı kadınlara ve erkeklere adalet sağlamak ve hukuka karşı eşitliği kurabilmektir. İran İslam Cumhuriyeti anayasasında kadın hakları ve sorumlulukları İslam dini referans alınarak ve dinî hukuka dayanılarak hazırlanmıştır. Söz konusu yasalarda iki önemli konu öne çıkmaktadır. Birincisi kadınların sahip olduğu haklar, ikincisi ise kadınların görevleridir. Ayrıca kadınlarla ilgili oluşturulan toplumsal ve kültürel konseyin bu yasalar bağlamında her iki yılda bir İran'daki kadınların durumunu denetleyerek gelişmeleri rapor halinde devrimin kültürel üst konseyine sunması gerekmektedir.

\subsection{1. İran İslam Cumhuriyeti Anayasasına Göre Kadınların Özlük Hakları ve Sorumlulukları}

1. Sağlıklı bir hayat ve fizikî olarak güvende yaşama hakkı

2. Sayg1 ve sevgi çerçevesinde yaşama hakkı

3. Düşünce özgürlügü ve düşünce emniyeti hakkı

5. Ahlak ve erdem çerçevesinde yaşama hakk1 ve sorumluluğu

6. Özel hayatta tacizden ve rahatsız edilmekten korunma, canını, malını ve onurunu koruma hakk1 ${ }^{42}$

${ }^{41}$ Seyyid Abbas Hoseyni-yi Nik, Mecmue-yi Gevanin-i Karbordi, ( Tahran: Mecme-yi İlmi ve Ferhengi-yi Mecd, 1384 hş), 7, İran İslam Cumhuriyeti Ana Yasa 20. Madde.

42 Hoseyni-yi Nik, Mecmue-yi Gevanin-i Karbordi,8, İran İslam Cumhuriyeti Ana Yasa 21. Madde, F1kra 1-5. 


\subsection{2. İran İslam Cumhuriyeti Yasalarına Göre Kadınların Özlük Hakları ve Sorumlulukları}

1. Yasaların uygulanma sürecinde her türlü eşitsizlikten uzak kalabilme hakk1

2. Adına ve kütüğüne sahip olma ve istediğinde değiştirebilme hakkı

3. İran vatandaşlığına sahip olma ve istediğinde vazgeçebilme hakkı

4. Kurallar çerçevesinde dinin farzlarını ve geleneklerini yerine getirme hakk1

5. Ahlak kuralları çerçevesinde yerel dilini, kıyafet ve geleneklerini kullanma hakk1

6. Maddi ve manevi zararlardan korunma hakk1

7. Kadın ve erkek arasındaki biyolojik farklılıkların korunması ve sorumluluğu

8. Sağlıklı bir çevrede yaşama ve bu çevreye karşı sorumlu olma hakk1 ${ }^{43}$

\subsection{3. İran İslam Cumhuriyeti Yasalarına Göre Kadınların Evlilikle İlgili Hakları ve Sorumlulukları}

1. Kadının maddi açıdan bağımsızlık hakkı

2. Kadının nikâh esnasında evlilik sözleşmesi şartlarını kullanma ve uygulama hakk1

3. Evlilik ve boşanma için resmi ve yasal makamlara başvuru hakkı

4. Maddi olarak belirlenen mihir hakk1

5. Düzenli nafaka hakk1

6. Çocuğunu emzirmek için babadan maddi gelir isteme hakk1

7. Evde çalıştığ 1 işin maddi karşılığını isteme hakkı

8. Evlilik sözleşmesinde erkeğin de kabul ettiği durumda evliliği sonlandirabilme hakk1

43 Zehra Ayetullahi, Şerh-i Menşur-i Hukuk ve Mesuliyetha-yi Zenan der Nizam-i Cumhuri-yi İslami-yi Iran, ( Tahran: Şura-yi İctimayi-yi Zenan ve Hanevade, 1391 hş), 15. 
9. Geri dönüş hakkıyla recii boşanma hakkı (boşandıktan sonra "idde" döneminde üç aya kadar eşiyle oturduğu evde kalmak ve nafaka almaya devam etmek suretinde)

10. Miras alma hakk1

11. Cinsel ilişki hakk1

12. Fiziksel ve zihinsel sağlık garantisi hakk1

13. Evlilik sözleşmesi varsa maddi ve manevi tazminat hakk1

14. Doğurganlık ve doğurganlığın zararlarından korunma hakkı

15. Evlilik sözleşmesi varsa ikamet ettikleri yeri seçme hakk1

16. Eşi 5 yıldan fazla hapiste ise boşanma hakkı

17. Erkek tarafından sebepsiz boşama durumunda erkeğin ortak malının yarısına sahip olma hakk1

18. Çiftlerin birbirlerine karşı saygılı ve hoşgörülü davranma hakkı

19. Evlilik öncesi beyanın evlilikle birlikte yalan olduğunun anlaşılmasıyla boşanma hakkı

20. Erkeğin oluruyla 7 yaşa kadar çocuklarının velayetine sahip olma hakk1

21. İhtiyaçlı anne-babayı koruma ve onlara bakma hakkı ve sorumluluğu,

22. Geçerli sebepler (bulaşıcı hastalık, uyuşturucu bağımlılığı, 5 yıldan fazla tutuklu veya hüküm giyme, ileri düzey psikolojik rahatsızlık gibi) nedeniyle şiddetli geçimsizlik durumunu ispat ederek eşten boşanabilme hakk1 ${ }^{44}$

\subsection{4. İran İslam Cumhuriyeti Yasalarına Göre Kız Çocuklarının Aile İçindeki Hakları ve Sorumlulukları}

1. Yasa ve yönetmeliklerin uygun gördüğü ebeveyne sahip olma hakk1

2. Ruhsal ve fiziksel sağlık ile temel ihtiyaçların sağlanması hakkı

44 Ayetullahi, Şerh-i Menşur-i Hukuk ve Mesuliyetha-yi Zenan der Nizam-i Cumhuri-yi Íslami-yi Iran, 17. 
3. Eğitim ve öğretim görme ve yeteneklerini geliştirme hakk1

4. Aile ve ebeveyn şiddetinden korunma ile duygusal ve ruhsal ihtiyaçların temini hakk1

5. Cinsiyet ayrımı olmaksızın ailenin imkânlarından yararlanma hakkı

6. Kimsesiz kız çocuklarının devlet himayesi altına alınması, koruyucu aile veya akraba velayetine geçme hakkı

7. Aile içinde diğer üyelere hoşgörülü ve saygılı davranma sorumluluğ $\mathrm{u}^{45}$

\subsection{5. İran İslam Cumhuriyeti Yasalarına Göre Kadınların Ekonomik Hakları}

1. Kendi malına ve mülküne sahip olma hakk1

2. Çalışma koşullarında erkeklerle eşit ücret alma ve menfaat eşitliği hakkı

3. Zorla çalıştırılmama, sert ve zararlı işlerden korunma hakkı

4. İş güvenliği ile güvenilir ve sağlıklı bir iş ortamında çalışma hakk1

5. Evlilik sürecinde kadın çalışsa bile erkek tarafından nafaka alma hakkı

6. Eş, baba ve evlat tarafından miras alma hakk1 ${ }^{46}$

\subsection{5. İran İslam Cumhuriyeti Yasalarına Göre Kadınların Cezai Hakları}

1. Aileye özgü davaları sürdürme hakk1

2. Kadınların; suçlanma, mağduriyet ya da suç işlemesi durumlarında, polis ve kolluk kuvvetlerine erişme, avukat tutma, avukat tutacak durumu yoksa devlet tarafindan hukukî müşavir desteği alabilme hakkı

3. Suçlanan kadınların; utanç verici eylemelere maruz kalmaktan, hakaretten ve bireysel-sosyal haklardan yoksun bırakılmaya karşı korunma hakk1

45 Ayetullahi, Şerh-i Menşur-i Hukuk ve Mesuliyetha-yi Zenan der Nizam-i Cumhuri-yi İslami-yi İran, 54.

46 Ayetullahi, Şerh-i Menşur-i Hukuk ve Mesuliyetha-yi Zenan der Nizam-i Cumhuri-yi İslami-yi İran, 163. 
4. Suçlanan kadınların hamilelik, emzirme, hastalık gibi durumlarda cezadan muaf tutulabilme hakk1

5. Suçlanan kadınların ebeveynlerini, çocuklarını ve eşlerini yasalara uygun olarak ziyaret etme hakk1

6. Yasalara ve insanlık onurunun korunması ilkesine uygun şekilde, kadın mahkûmların, hapishanede kaldıkları süre boyunca tesisleri kullanabilmeleri ve sağlıklı bir sosyal hayata dönmek için sağlık, kültür, eğitim alanında yeterli imkânlara sahip olma hakkı

7. Suçlu kız çocukları ve ergenlerin özel ıslah ve yetiştirme merkezlerinde uygun koşullarda korunma hakk1

8. Yasal vasisi yetkili ve yeterli değilse 18 yaşın altındaki kız çocukları için davanın savcı tarafından desteklenmesi hakkı. ${ }^{47}$

\subsection{Günümüzde İran'da Kadınların Siyasete Katılımı ve Katılım Engelleri}

Dünyanın her yerinde kadının siyaset ortamına girmesi modernitenin geç bir yansıması şeklinde olmuştur. Şöyle ki ağırlıkla erkekler tarafindan düzenlenen siyasetin genel kurallarına göre modernite öncesi ve modernitenin ilk dönemlerinde kadınlar siyasetten uzak tutulmuştur. Bu sebepten ötürü modern dönemde kadının toplumsal yapıda kendine yer arayışı ve siyasete girme çabası olağanüstü bir durum olarak algılanmıştır. İran kadınları da bu konuda istisna sayılmazlar, hatta başka ülkelere bakılınca kadın aktivistlerin faaliyetleri siyasî ve toplumsal yönden daha az ve daha renksizdir.

Kadının siyasete katılımı konusunda, dünyadaki gelişmeler ve bu gelişmelerin İran'daki yansımasının yanı sıra, İran'ın siyaset tarihindeki bazı olaylar kadınların siyasî ve toplumsal konumunu etkilemiştir. İran, coğrafya açısından farklı kavimlerin saldırılarına maruz kalan ve devamlı tehdit altında olan bir bölgedir. Bu sebeple İran'da sürekli siyasî yönden güvensizlik, emniyetsizlik hâkim olmuş, tarih boyunca da bu güvensizlik hep devam etmiştir. Bu durum aynı zamanda; siyaset, hukuk ve ekonomi gibi

47 Ayetullahi, Şerh-i Menşur-i Hukuk ve Mesuliyetha-yi Zenan der Nizam-i Cumhuri-yi Isslami-yi İran, 231. 
hususlardaki altyapının değişkenliğine sebep olmuş ve istikrarsız bir yapı meydana getirmiştir. Buna bağlı olarak toplumsal birliğin en net örneklerinden birisi sayılabilecek siyasî katılım da sürekli çelişkili bir durumda olmuştur. Kadınların siyasetteki katılımı ve konumu da her zaman bu durumdan etkilenmiştir. ${ }^{48}$

\subsection{Günümüz İran Siyasetinde Kadınları Engelleyen Cam Tavan Sendromu}

Dünyanın her yerinde olduğu gibi İran'da da kadınların aleyhine uygulanan cam tavan sendromu ve yapışkan zemin sendromu ile sürekli karşılaşılmaktadır. Siyaset alanında cam tavan sendromunun en büyük sebebi kadınların partilere üyeliğinin çok düşük oranlarda olmasıdır. Maalesef partilerin kuralları kadınlar için pek adil değildir. Sağlanabilecek kolaylıkların veya imkânların eşit bir şekilde paylaşılamaması, kadınların partilere üye olmasını engelleyen sebeplerden biri olarak sayılabilir. Kadınlar, parti üyesi olduklarında veya siyasetin herhangi bir alanında boy gösterdiklerinde sürekli problemlerle karşılaşmakta ve bu problemler hem sosyal hayatlar1$\mathrm{n} 1$ hem de aile yaşantılarını olumsuz etkilemektedir. İleri düzey demokratik toplumlarda bile aynı meselelerle bugün dahi karşılaşmak mümkündür. Siyaset, toplum ve eğitim alanlarında meydana gelen bütün gelişmelere rağmen kadınlar halen çok ciddi sıkıntılar yaşamaktadırlar. Gelişmiş ülkelerde kadınların potansiyel gücünü kullanmak için özellikle son 20 yılda pozitif ayrımcılığ 1 öne çıkaran çok ciddi yasal düzenlemeler yapılmış ve belli bir kontenjan partiler tarafından zorunlu bir şekilde kadın siyasetçilere ayrılmıştır. Maalesef siyasette pozitif ayrımcılık durumu İran'da pek gözükmemekte ve siyaset sahasında erkek ve kadın sayısını dengede tutmak gibi bir mesele önemsenmemektedir.

Günümüz İran'ında Cumhurbaşkanının Aile ve Kadın Sorunları Danışma$\mathrm{n} 1$ Şahindoht Molaverdî şöyle söylemektedir:

"Kadınların katılımı olmadan siyasî hedeflerimizin şekillenmesinde kesinlikle tam bir başarı elde edemeyiz, ama maalesef

48 Huseyn Mesudniya; Mina Nezeri, "Huzur-i Zenan Der Kuvve-yi Mugennene Tehevvulat-i Gabl ve Ba'd ez İnkilâb-i İslamî”, Zen Der Tovsie-yi Siyaset, no 4. (1392 hş): $575-589$. 
İran'da kadınların eğitiminin yükselmesine rağmen, onların çalışabilecekleri, eğitimlerinin getirisini kullanabilecekleri ve karar verme güçlerini işe katmalart için pek imkân gözükmemektedir. Hâlbuki gelişmişlik ile kadınların katılımı arasında çift tarafl bir iletişim mevcuttur. Kadınların gitgide artan katıllmlarl, gelişmişlik düzeyinin arttı̆̆ının da göstergesidir."

Molaverdî, İran'ın uluslararası taahhütlerini vurgulayarak kadınların siyasete katılımının artması için daha çok çaba gösterilmesi gerektiğini özellikle vurgulamaktadır.

Bu bağlamda başka bir büyük problem ise kadınların özellikle meclis seçimlerinde ve ulusal seçimlerde aday adayı olmaları yönünde ciddi engellerin olması ve dahası sürekli reddedilmeleridir. Durum böyle olmasına rağmen yine de günümüz İran siyasetinde Yenilikçi Kadınlar Partisi'nin sekreteri olan Fateme Rakî̂, "Kadınların siyasî katılımını geliştirmek adlna yasalar ve partiler tarafindan kadınlar için bir katılım oranı belirlenmesi gerektiğini" ileri sürmektedir. Kadınlar için belli bir yüzdenin ayrılmaması durumunda onların siyasette boy göstermesinin imkânsız olduğuna vurgu yapan Rakiî, kadınların siyasî katılımlarının artması ve siyasete teşvik edilmeleri için liberaller dönemindeki gibi partilerde kadınlar için ayrılmış kürsülerin tekrar kullanıma sokulmasını talep etmektedir. Ona göre; kadınların siyasette başarılı olmaları için yapılan teşvikler sadece kültürel yardımlarla sınırlı olmamalı, aynı zamanda maddi ve manevi destek de sunulmalıdır. Herhangi bir destek söz konusu olmadığı gibi kadınlar bu alanda negatif ayrımcılığa da uğramaktadır. Rakî̂, erkeklerin siyaset alanında birbirlerine daha hoşgörülü olduklarını, muhalif bile olsalar ciddi makamları kendi aralarında paylaşabildiklerini, fakat başarılı kadın yöneticilere, kadın siyasetçilere karşı ön yargı beslediklerini ve tepkili olduklarını da ifade ederek onları tenkit etmektedir. ${ }^{49}$

\section{Sonuç}

Eski bir medeniyete ve zengin geçmişe sahip olan İran coğrafyasında geleneklerin, adetlerin ve hatta eski mitlerin hâkim olduğu gözükmekte iken, bu ülkenin sanayileşmiş Batı medeniyeti ile iletişime geçmesiyle birlikte

49 Fatemeh Rake'yi; Hüseyin Ahmedi, "Zaruret-i Teğyirat-i Bonyadin der Hukuk-i Zenan”, Baztab-i Endişe, no. 87, (1386 hş): 67-89. 
toplumun ekonomi ve siyasetinde kökten değişimler görülmeye başladı. $\mathrm{Bu}$ değişim ve dönüşümlerin sonucu olarak kadınların -özellikle şehir kadınlarının- hayatındaki alışkanlıklar ve daha sonraki aşamada onlarla ilgili yasalar değişmeye başladı. İslam'dan sonra uzun süre hep perde arkasında görünmez olan toplumun yarısı, görünmeye ve hatta toplum üzerinde etki bırakmaya başladı. Kaçarlar dönemi bu coğrafyanın kadınlarının hayatında en ağır dönem sayılabilir. Yaklaşık yüz yıllık bir süreçte kadınlar yok olmaktan dergi ve gazetede yazı yazabilecek düzeye kadar yükselmeyi başardılar. Eğitim ve sağlık hakları elde edebildiler. Eğer kadınların İslam'dan sonraki 1200 yıllık kültürel yolculuğuna bakılırsa bu sürecin toplum üzerindeki etkisi rahatça fark edilebilir ve bu sürecin genel seyir içerisinde ne kadar kısa olduğu görülür. Bu durumda mevcut hızlı değişimin hem toplum hem de kadınların ruhunda derin izler bırakması gayet normaldi. Ayrıca ilgimizi çeken en önemli noktalardan biri de bu hareketlenmenin başarısında eğitimli ve ileri görüşlü erkeklerin desteğiydi.

Yukarıda bahsi geçen aydınların desteği ile kadınlara özgü dergiler ve dernekler şekillenmiş ve toplumun bilinçlenmesini sağlayarak, kadın haklarına giden yolun açılmasına katkı sağlamış ve kolaylaştırmışlardır. Bu dergiler ve derneklerin aracılığıyla toplumdaki orta kesim kadınlar, hakları konusunda uyarılıp bu hakları talep etmek için güçlenmişlerdir. Daha sonra aynı aydınlar, özellikle aydın kadınlar, ilk kız çocuk neslini eğiterek kendileri ile aynı düşünceye sahip yeni kuşak yetiştirip bu mücadeleyi daha da güçlü bir şekilde devam ettirmişlerdir. Elbette ki bu arada Meşrutiyet mücadelesinde tütün olayındaki eğitimsiz ama bilinçli alt kesim kadınlarının da mücadelesi unutulmamalıdır.

Bütün bu olanların sonucu olarak Kaçarların son döneminde kadınlar, kendilerine ait hakların büyük bölümünü (bütün kadınlar için bile olmasa) elde etmeyi başarmışlardı. Bu mücadeleler Pehleviler döneminde, Batı hayranlığının ve ara sıra kendi siyaseti içindeki kargaşanın sonucu olarak kadınların daha da güç kazanmasına ve siyasi haklarını (yine belli bir kesime ait olsa bile) elde edebilmesine ortam sağladı. Bu süreçte iki siyasi geçiş dönemi (1. Kaçarlardan Rıza Şah hükümetine geçiş süreci, 2. Rıza Şah'dan Muhammed Rıza Şah hükümetine geçiş süreci) kadınlar için büyük fırsat oldu. Bu dönemlerde siyasetin kendi içinde çelişmesi nedeniyle kadınlar da konuşma ve varlıklarını ortaya koyma şansı buldular. Hatta daha sonra elde edilen siyasi başarı da bu dönemin sonucu oldu denilebilir. 
İran İslam Devrimi'nden hemen sonra ilk kez bütün kadınlar tüm bu haklara sahip oldular. Bu dönem İran kadının en özgür ve en parlak dönemidir demek pek yanlış olmayacaktır. Devrimin başarısında derinden etkili olan kadınlar, devrimden sonra da toplum ve siyasetin kilit noktalarında yer edinmeyi başardılar. Yeni anayasanın getirdiği keskin kurallar da bu süreçte özellikle kız çocuklarının yararına birçok gelişmeye sebep oldu.

Sekiz yıl süren savaşta kadınların gücü hem savaş cephelerinde hem arkadaki duygusal destekte önem taşıdı. Ama maalesef bu yıpratıcı süreçte biraz korunma amaçlı, biraz da savaştan kaynaklanan eril ortamın daha fazla güçlenmesi, yavaş yavaş kadınların yeniden arka plana gönderilmesine yol açtı. Bu düşünce daha sonra büyümeye başlarken, devrimden sonra elde edilen siyasi özgürlükler tekrar kısıtlanmaya başladı. Günümüz İran'ında toplumda ve özellikle siyaset alanında pek gözükmeyen kadınlar, eğitim, sağlık gibi alanlarda yeterince başarılı ve güçlüdür. Bunun en büyük destekçisi ise yasalardan ziyade, her zaman kadından yana olan kültür ve geleneksel eğitim sistemidir. Modern İran kadınları siyaset dünyasında cam tavan sistemi ile mücadele etse bile iş ortamlarında, toplumda, ticarette, eğitimde, sağlıkta ve sporda güçlerini korumayı başarıp, üst basamaklara hem ulusal ve hem uluslararası çapta yükselmektedir.

Netice itibariyle inceleme tarihsel bir değerlendirme olmakla birlikte, analitik süreç tahliline ve bilhassa son dönemi için geçerli olacak şekilde de gözleme dayanmaktadır. Kadının beşerî ve iradî gelişiminde mekân, zaman ve salt toplumsal itkiyle birlikte değerlendirmeye tabi tutulması bile onun insanlık serüveninde haksızlığa maruz kalmasının doğal bir sonucudur. İnsan temelli değerlendirme yapılana dek cinsiyet kıyaslamasının her zaman eşitsizliğe götüren değerlendirmelere sebebiyet vereceği açıktır. Ancak bir toplumda gelişim, dezavantajlıların da normal kabul edilmesiyle mümkün olacaktır. Bunun ise tüm değerlerden, inançlardan, siyasî ve sosyal kavramlardan öte olan yaşama hakkı ekseninde varılacak kavrayışla yerleştirileceği malumdur.

\section{Kaynakça}

Abdollahifard, Pouneh. "Kavramlar ve Kuramlar, Düşünce Bilimleri” içinde Iran Mitolojisinde Cinsiyet Eşitliği, (ed.) M. Nesim Doru- Kamuran Gökdağ, 575-591. Mardin: MAÜ Yayınları, 2020. 
Abdollahifard, Pouneh. "Nima Yuşic 'ten 1979'a kadar Fars Şiiri”, Doktora Tezi, Atatürk Üniversitesi, 2018.

Abdollahifard, Pouneh. "Toplumsal Cinsiyet Bağlamında Siyasi Kimlik ve Temsil: Yerel Seçimler Örneğinde Kadın Politikacıların Seçim Afişlerindeki Mitler Üzerine Göstergebilimsel Bir İnceleme" Doktora Tezi, Atatürk Üniversitesi, 2019.

Abdollahifard, Pouneh. "Zerdüşt İnancında Kadının Konumu." Doğu Esintileri, no. 13, (2020): 263-286.

Ahmedi-yi Horasani, Nuşin. "Ez Mehafil-i Zenane ta Teşekkolha-yi Müstekil-i Zenan, Rahi be Suye Came'e-yi Medeni." Ferheng ve Tose'e, Kadınlara Özel Sayı, (1376 hş.): 83-112.

Ayetullahi, Zehra. Şerh-i Menşur-i Hukuk ve Mesuliyetha-yi Zenan der Nizam-i Cumhuri-yi İslami-yi Iran, Tahran: Şura-yi İctimayi-yi Zenan ve Hanevade, 1391 hş.

Bağdar-i Dilgüşa, Ali. "Berrisi-i Mutalibat-i Zenan der Metbuat i Dore- yi Meşrutiyet." Yüksek lisans Tezi, Firdevsi Üniversitesi, Mashad, 1394 hş.

Bakinejad, Abbas. Teemmuli der Edebiyat-i Imruz-i Iran, Tahran: Parsi, 1387 hş.

Bamdad, Bedrolmoluk. Ez İnkilab-i Meşrutiyet ta İnkilab-i Sefid, Tahran: İbn-i Sina, 1347 hş.

Beşeri, Delriş. Zen der Dore-yi Kaçar, Tahran: Sazman-i Tabligat-i İslami, 1375 hş.

Eyvezi, Muhammed Rahim. "Zenan-i İrani Der Meclis-i Şura-yi İslama”, Zen Der Tovse'e ve Siyaset, no 15 (1393 hş.): 112-126.

Hoseyni-yi Nik, Seyyid Abbas. Mecmue-yi Gevanin-i Karbordi, Tahran: Mecme-yi İlmi ve Ferhengi-yi Mecd, 1384 hş.

Hüsrevpenah, Muhammed Hüseyin. Hedefha ve mobareze-i Zen-i Irani ez Inkilab-i Meşrute ta Saltanat-i Pehlevi, Tahran: Peyam-i İmruz, 1381 hş.

İttihadiyye, Mansureh. "Zen der Came'e Kaçar”, Kelk Dergisi, no. 55, (1373 hş.): 47-62.

Kar, Mihrengiz. Muşareket-i Siyasi-yi Zenan, Tahran: Roşengeran, 1379 hş. 
Kerbelayi, Hasan. Karardad-i Reji ya Tarih-i Inhisar-i Duhhaniyat, Tahran: Mobarizan, 1361 hş.

Kesrayi, Siyaveş. Çaliş-i Sonnet ve Modernite der Iran, Tahran: Neşr-i Merkez, 1384 hş.

Koulaee, Elaheh. "Women in the Parliament," Women, Power and Politics in 21st Century Iran, ed. Tara Povey and Elaheh Rostami-Povey, (2016): 137-151.

Mesudniya, Huseyn; Nezeri, Mina. "Huzur-i Zenan Der Kuvve-yi Mugennene Tehevvulat-i Gabl ve Ba'd ez İnkilâb-i İslamî”, Zen Der Tovsie-yi Siyaset, no. 4. (1392 hş.): 575-589.

Muhit Tabatabayi, Muhammed. Tarih -i Tahlili-yi Matbuat-i Iran, Tahran: Be'sat, 1369 hş.

Musaffa, Nasrin. Muşariket-i Siyasi-yi Zenan der Iran, Tahran: İntişarat-i Vezaret-i Umur-i Harece, 1375 hş.

Natık, Homa. "Negahi be Barhi Neveşteha ve Mobarezat-i Zenan der Dore-yi Meşrutiyet", Kitab-i Com'e, no. 30, (1358 hş.): 45-54.

Pervin, Maryam. “İnkilab-i Meşrute ve Conbeş-i Zenan”, Yad-i Eyyam, no. 59, (1389 hş.): 75-89.

Rake'yi, Fatemeh. Ahmedi Hüseyin. "Zaruret-i Teğyirat-i Bonyadin der Hukuk-i Zenan”, Baztab-i Endişe, no. 87, (1386 hş.) 67-89.

Ravendi, Morteza. Tarih-i İctimai-yi Iran, c. 1, Tahran: Nigah, 1365 hş.

Sansariyan, Eliz. Conbeş-i Hukuk-i Zenan der Iran, çev. Nuşin Ahmedi, Tahran: Ahteran, 1384 hş.

Sarıkaya, Yalçın. "Geçmişten Günümüze İran”, Tarih, Siyaset, Toplum ve Kültür, Tasav, Rapor no. 2. (Ankara, 2012): 1-39.

Semii İsfehani, Ali Rıza. "Revş ve Nezeriye-yi Feministi", Pejuheşnameyi Ulum-i Siyasi, no. 18, (1392 hş.): 153-168.

Tacussaltana. Hatirat, tsh, Mansure İttihadiye, Tahran: Neşr-i Tarih-i İran, 1371 hş.

Üstün, İsmail Safa. “İran”, DİA, XXII, İstanbul, 2002. 